\title{
Genetic merit for fertility traits in Holstein cows: V. Factors affecting circulating progesterone concentrations
}

\author{
S. G. Moore, ${ }^{*} \dagger$ S. Scully, $\dagger$ J. A. Browne, $\dagger$ T. Fair, $\dagger$ and S. T. Butler ${ }^{* 1}$ \\ *Animal and Grassland Research and Innovation Centre, Teagasc, Moorepark, Fermoy, Co. Cork, Ireland \\ †School of Agriculture and Food Science, University College Dublin, Belfield, Dublin 4, Ireland
}

\section{ABSTRACT}

This study investigated the factors affecting circulating progesterone (P4) concentrations in cows with similar genetic merit for milk production traits, but with extremes of good (Fert+) or poor (Fert-) genetic merit for fertility traits. Study 1: 28 cows were enrolled in an ovulation synchronization protocol at $61 \pm 13$ ( \pm standard deviation) days postpartum, and data are presented for 13 Fert + and 9 Fert - cows that remained in the study. Progesterone concentrations were determined from d 0 to 9 (d 0 = estrus) and on d 7, corpus luteum (CL) volume and blood flow area (BFA) were measured by B-mode and Doppler ultrasonography, respectively. Cows were administered $\mathrm{PGF}_{2 \alpha}$ on $\mathrm{d} 7$ in the p.m. and $\mathrm{d} 8$ in the a.m. to regress the CL, and 2 controlled internal drug release devices were inserted per vaginum on $\mathrm{d} 8$ in the a.m. Liver biopsies were collected on d 9 and hepatic mRNA abundance of genes involved in P4 catabolism was determined. On d 10, the controlled internal drug release inserts were removed and frequent blood samples were collected to measure the rate of decline in circulating $\mathrm{P} 4$. The Fert + cows tended to have greater dry matter intake compared with Fert - cows $(+0.79 \mathrm{~kg}$ of dry matter $/$ d), but similar milk production $(29.82 \mathrm{~kg} / \mathrm{d})$. After synchronized ovulation, the rate of increase in circulating P4 concentrations was greater in Fert+ cows compared with Fert- cows. No effect of genotype on CL volume was detected, but BFA was $42 \%$ greater in Fert+ cows compared with Fert- cows. The Fert- cows had greater mRNA abundance of cytochrome P450, family 3, subfamily A (CYP3A) compared with Fert+ cows, but the mRNA abundance of aldo-keto reductase family 1, member C1 (AKR1C1), AKR1C3, AKR1C4, and cytochrome $\mathrm{P} 450$, family 2 , subfamily $\mathrm{C}(C Y \mathrm{P} 2 C)$ were similar. The half-life and metabolic clearance rate of $\mathrm{P} 4$ were similar in Fert+ cows and Fert- cows. Study 2: 23 cows were enrolled in an ovulation synchronization protocol at $55 \pm 7$ ( \pm standard deviation) d postpartum,

Received March 13, 2014.

Accepted May 11, 2014.

${ }^{1}$ Corresponding author: stephen.butler@teagasc.ie and data are presented for 13 Fert+ and 8 Fert- cows that remained in the study. On d 4, 7, 10, and 13 (d 0 = estrus), CL volume and BFA were measured as in study 1 . Progesterone concentrations were measured from d 1 to 13 . Corpus luteum volume was $41 \%$ greater in Fert+ cows compared with Fert- cows but no effect of genotype on BFA was detected. Mean circulating P4 concentrations were $79 \%$ greater in Fert+ cows compared with Fert-cows. Milk yield was similar in both genotypes. The results indicate that greater circulating P4 concentrations were primarily due to greater CL P4 synthetic capacity rather than differences in $\mathrm{P} 4$ clearance in this lactating cow genetic model of fertility.

Key words: genetic merit for fertility, progesterone, progesterone metabolism, corpus luteum

\section{INTRODUCTION}

Progesterone $(\mathbf{P} 4)$ is an important regulator of events during the estrous cycle and is essential for the maintenance of pregnancy. The well-documented decline in fertility in dairy cows has been attributed to increased occurrence of embryo mortality, particularly during the period before maternal recognition of pregnancy (Diskin and Morris, 2008), which has been associated with inadequate circulating $\mathrm{P} 4$ concentrations during diestrus of the estrous cycle that preceded insemination and fertilization (Lonergan, 2011). Indeed, several studies have reported an improvement in fertility performance when cows were placed on synchronization protocols with supplemental $\mathrm{P} 4$ before ovulation (Xu et al., 1997; Herlihy et al., 2011; Colazo et al., 2013). Reduced circulating concentrations of $\mathrm{P} 4$ during preovulatory follicle development facilitates increased $\mathrm{LH}$ pulsatility, greater incidence of multiple ovulations, lower likelihood of conception after AI, and increased likelihood of embryo mortality between d 30 to 60 after AI (Cunha et al., 2008; Wiltbank et al., 2011). For successful maternal recognition of pregnancy, the developing embryo must be capable of producing sufficient IFN- $\tau$. This is more likely if a rapid increase in circulating $\mathrm{P} 4$ concentrations occurs after fertilization, which alters the endometrial transcriptome and protein 
secretions to promote development of a larger embryo (Forde et al., 2013). In support of this, studies have reported positive associations between milk $\mathrm{P} 4$ concentrations (Stronge et al., 2005; McNeill et al., 2006) or P4 supplementation (Larson et al., 2007) during the period before blastocyst hatching and subsequent pregnancy success.

Circulating $\mathrm{P} 4$ concentration during the estrous cycle is a balance between the $\mathrm{P} 4$ synthetic capacity of the corpus luteum (CL) and the metabolic clearance rate (MCR) by the liver. Factors affecting P4 secretion include the number of luteal cells, luteal cell steroidogenic capacity, and ability to export P4 (Wiltbank, 1994). Per unit volume, the CL experiences the greatest blood flow of any endocrine organ, which is central to its function, particularly for the efficient uptake of cholesterol and for P4 secretion (Wiltbank, 1994). Mann (2009) reported a strong correlation between CL tissue mass and circulating $\mathrm{P} 4$ concentrations on $\mathrm{d} 5$ of the estrous cycle $\left(R^{2}=0.64\right)$, but no correlation on $d 8\left(R^{2}=0.04\right)$ or d $16\left(\mathrm{R}^{2}=0.02\right)$, suggesting increased importance of luteal cell steroidogenic activity or CL blood flow as the CL matures. The factors that affect P4 MCR include liver blood flow and the activity of liver enzymes with P4 catabolic activity. Because liver blood flow is positively associated with DMI (Sangsritavong et al., 2002; Reynolds et al., 2003), increased liver steroid clearance has been implicated as a potential disruptor of reproductive events, due to lower circulating concentrations of P4 and estradiol (E2; Sangsritavong et al., 2002). In addition, Lemley et al. (2010a) demonstrated that the liver expression of cytochrome P450 3A and $2 \mathrm{C}$ and aldo-keto reductase family 1 , member $\mathrm{C}$ genes, which are involved in $\mathrm{P} 4$ inactivation, can be altered by dietary manipulation. Therefore, possible causes of low circulating $\mathrm{P} 4$ concentrations include inadequate CL P4 synthesis, increased liver blood flow, and greater liver P4 catabolic enzyme activity.

Previously, we have reported positive effects of genetic merit for fertility traits on the reproductive performance of dairy cows (Cummins et al., 2012a), a phenotype associated with greater circulating $\mathrm{P} 4$ concentrations during the estrous cycle (Cummins et al., 2012b). Therefore, 2 consecutive studies were carried out to identify the physiological mechanisms associated with greater circulating $\mathrm{P} 4$ concentrations in dairy cows with high genetic merit for fertility traits.

\section{MATERIALS AND METHODS}

\section{Animal Model}

A genetic model of fertility was established in Teagasc Moorepark (Fermoy, Co. Cork, Ireland) to elucidate the mechanisms responsible for poor fertility in lactating Holstein dairy cows (Cummins et al., 2012a,b,c). In the autumn of 2007 and 2008, nulliparous spring-calving heifers were identified from the national dairy cattle database (Irish Cattle Breeding Federation, Bandon, Ireland). This population was limited to animals with EBV for milk production between +200 and +900 $\mathrm{kg}$ and $>75 \%$ Holstein genetics. Within this population, heifers with extreme positive [i.e., poor fertility $($ Fert-)] or negative [i.e., high fertility $($ Fert+)] EBV for calving interval were selected. Only Fert- heifers from sires and maternal grand-sires with positive EBV for calving interval and Fert+ heifers from sires and maternal grand-sires with negative EBV for calving interval were selected. Nulliparous Fert- and nulliparous Fert+ heifers that passed the Moorepark Biosecurity Protocol were purchased and moved to the Moorepark Animal and Grassland Research and Innovation Centre (Fermoy, Co. Cork, Ireland). Within the Irish national herd, these heifers were representative of the top $25 \%$ in genetic merit for milk production. The Fert- heifers represented the bottom $5 \%$ in genetic merit for calving interval, whereas the Fert+ heifers represented the top $20 \%$ in genetic merit for calving interval. In subsequent years, herd replacements were generated by selecting suitable sires to maintain the difference in genetic merit for calving interval. The list was restricted to sires with $>200 \mathrm{~kg}$ PTA for milk production, $>0 \%$ PTA milk fat and protein concentrations, and $>75 \%$ Holstein genetics. From this group, sires with $>5$ d PTA for calving interval were selected for mating with the Fert- cows and sires with $<-5 \mathrm{~d}$ PTA for calving interval were selected for mating with the Fert+ cows. Twenty-eight and 23 cows were enrolled in study 1 and 2, respectively, and the EBV of the cows from both genotypes are summarized in Table 1. In study 1, Fert+ and Fertcows were represented by 5 and 11 sires, respectively. In study 2, Fert+ and Fert- cows were represented by 6 and 9 sires, respectively. Seventeen cows (9 Fert+ and 8 Fert-) were enrolled in both studies. The experimental procedures involving animals in both studies were licensed by the Department of Health (Dublin, Ireland) in accordance with the Cruelty to Animals Act (Ireland 1876) and the European Community Directive 86/609/ EEC.

\section{Study 1}

Feed and Management System. The study was undertaken at Teagasc Moorepark from November 2010 to March 2011. Mean calving dates were November 2 (SD: $\pm 37.1 \mathrm{~d}$ ) and November 6 (SD: $\pm 37.9 \mathrm{~d}$ ) for the Fert+ and Fert- cows, respectively. Following parturition, cows were housed as 1 group in a freestall barn. 
Table 1. The mean $\mathrm{EBV}^{1}$ (SD) for both genotypes based on their sire, maternal grandsire, and maternal great grandsire EBV

\begin{tabular}{|c|c|c|c|c|}
\hline \multirow[b]{2}{*}{ Variable } & \multicolumn{4}{|c|}{ Genotype $^{2}$} \\
\hline & Fert+ & Fert- & Fert+ & Fert- \\
\hline No. of animals & 15 & 13 & 13 & 10 \\
\hline Holstein & $90.4(7.2)$ & $94.9(7.0)$ & $95(4.7)$ & $95(5.8)$ \\
\hline Milk (kg) & $363(152)$ & $434(125)$ & $417(163)$ & $445(141)$ \\
\hline Protein $(\mathrm{kg})$ & $15(5.7)$ & $16.8(4.9)$ & $18(7.0)$ & $19(5.8)$ \\
\hline Protein $(\mathrm{g} / \mathrm{kg})$ & $0.33(0.60)$ & $0.35(0.64)$ & $0.58(0.59)$ & $0.59(0.70)$ \\
\hline Survival (\%) & $3.62(0.94)$ & $-2.67(2.04)$ & $3.64(0.83)$ & $-3.34(1.17)$ \\
\hline Calving interval $(\mathrm{d})$ & $-6.02(1.46)$ & $8.05(2.67)$ & $-6.48(1.34)$ & $7.98(2.99)$ \\
\hline Sire calving interval $(\mathrm{d})$ & $-9.9(1.9)$ & $10.7(3.7)$ & $-9.2(2.6)$ & $11.9(3.5)$ \\
\hline Maternal grandsire calving interval (d) & $-6.0(2.1)$ & $12.7(5.4)$ & $-8.2(3.5)$ & $11.2(4.5)$ \\
\hline
\end{tabular}

${ }^{1}$ Predicted transmitting ability values were obtained from the autumn 2012 official dairy evaluations published by the Irish Cattle Breeding Federation (http://www.icbf.com/services/evaluations/dairy.php) and multiplied by 2 to convert to EBV. Individual cow EBV were determined using the following formula: $0.5 \times$ sire EBV $+0.25 \times$ maternal grandsire EBV $+0.125 \times$ maternal great grandsire EBV.

${ }^{2}$ Fert $+=$ good-fertility cows; Fert $-=$ poor-fertility cows.

${ }^{3}$ In study 1 , the parity structure for the Fert + cows was 4 and 11 cows in second and third lactation, respectively. The parity structure for the Fert- cows was 9 and 4 cows in second and third lactation, respectively.

${ }^{4}$ In study 2, the parity structure for the Fert+ cows was 3,4 , and 7 cows in second, third, and fourth lactation, respectively. The parity structure for the Fert- cows was 1, 3, and 6 cows in second, third, and fourth lactation, respectively.

Starting at d 40 (SD: $\pm 15 \mathrm{~d}$ ) postpartum, DMI was recorded daily using the Griffith Elder feeding system (Griffith Elder Ltd., Bury St Edmunds, UK). Cows were fed a TMR ad libitum plus $5 \mathrm{~kg}$ of lactating cow concentrate per day at the a.m. and p.m. milkings. Feed refusals were removed every second day. Diet ingredients were sampled weekly and composited monthly for analysis.

Animal Measurements. Cows were milked twice daily at 8 a.m. and 4 p.m. Milk yield was recorded at each milking using electronic milk meters (Dairymaster, Causeway, Co. Kerry, Ireland). Milk composition (fat, protein, and lactose) was determined weekly from successive a.m. and p.m. samples by mid-infrared reflectance spectroscopy (FT6000 MilkoScan instrument; Foss Electric A/S, Hillerød, Denmark). Body weight and BCS were recorded weekly. Body condition score was assessed using the 1 to 5 scale in 0.25 increments (Edmonson et al., 1989).

Ovulation Synchronization. Cows were enrolled in an ovulation synchronization protocol involving a controlled internal drug release (CIDR) device and timed AI (TAI) $18 \mathrm{~h}$ after CIDR removal (CIDR_TAI) as previously described by Herlihy et al. (2012). The mean days postpartum $( \pm \mathrm{SD})$ when cows were enrolled in the protocol was $61 \pm 15$ (range: $37-78$ ) and 60 \pm 13 (range: $35-78$ ) for the Fert+ and Fert- cows, respectively. On $\mathrm{d}-10$, each cow was administered an i.m. injection of a $\mathrm{GnRH}$ agonist containing $10 \mu \mathrm{g}$ of buserelin (Receptal; Intervet Ireland, Dublin, Ireland), and a CIDR device containing $1.38 \mathrm{~g}$ of P4 (Pfizer Ire- land, Dublin, Ireland) was inserted per vaginum. On $\mathrm{d}-3$, each cow was administered an i.m. injection of $\mathrm{PGF}_{2 \alpha}$ containing $25 \mathrm{mg}$ of dinoprost tromethamine (Lutalyse; Pfizer Ireland). On $d-2$, the CIDR device was removed and $36 \mathrm{~h}$ later, each cow was administered a second i.m. injection of GnRH agonist.

Blood Sampling. Blood samples were collected once daily on $\mathrm{d}-3,-2$, and -1 (before the a.m. milking) and twice daily on d $0,1,2,3,4,5,6,7,8$, and 9 at 12 -h intervals relative to synchronized estrus (d 0 ) by coccygeal venipuncture into Vacutainers containing lithium heparin (Becton Dickinson, Plymouth, UK), and centrifuged at $2,000 \times g$ for 15 min at $4^{\circ} \mathrm{C}$; plasma was decanted and stored at $-20^{\circ} \mathrm{C}$.

Ovarian Ultrasonography. Transrectal ultrasound examinations of both ovaries were carried out on $\mathrm{d} 0$ and 7 relative to the synchronized estrus. On d 0 , follicles $\geq 5 \mathrm{~mm}$ on the ipsilateral and contralateral ovaries were recorded. The clearest image of the largest follicle was frozen, and the cross-sectional height and width were measured using the internal caliper of the ultrasound machine $(7.5-\mathrm{MHz}$ transrectal transducer, Aloka SSD-900; Aloka Ltd., Tokyo, Japan). On d 7, the CL that developed from the ovulatory follicle was examined using a Voluson i ultrasound machine (GE Healthcare Systems, Vienna, Austria) equipped with a $12-\mathrm{MHz}$ linear array probe. Initially, CL were visualized in B-mode, and 3 images of each CL at its maximum diameter were captured and stored for further analysis. Ultrasound machine settings were then switched to power Doppler mode. The entire CL at its maximum 
size was fitted within a Doppler sample box and scanned for several seconds. Three images of each CL deemed representative of maximum blood flow with no flash artifacts were captured and stored for further analysis.

$P 4$ Clearance. Each cow was administered an i.m. injection of $\mathrm{PGF}_{2 \alpha}$ on $\mathrm{d} 7$ in the p.m. and $\mathrm{d} 8$ in the a.m. On $\mathrm{d} 8$ in the a.m., 2 CIDR, each containing 1.38 $\mathrm{g}$ of $\mathrm{P} 4$ were inserted per vaginum and an indwelling jugular catheter was inserted to facilitate frequent blood sampling. Cows were moved to an individual tie-stall barn. On d 9, a liver biopsy was collected from each cow. The biopsy site on the right flank was clipped, shaved, disinfected with Videne (povidone-iodine, 7.5\%; Ecolab Healthcare, Leeds, UK) and methylated spirits, and anesthetized with Willcain (procaine hydrochloride, 5.0\%; Dechra Ltd., Shrewsbury, UK). A 1 -cm incision was made through the skin between the 11th and 12th ribs and the biopsy tool was inserted to pierce the intercostal muscle and peritoneum. The liver was located and a 1- to 1.5 -g sample was removed. The sample was washed in saline, blotted dry, snap frozen in liquid nitrogen, and stored at $-80^{\circ} \mathrm{C}$. The incision site was sutured and treated topically with oxytetracycline spray (Duphacycline; Interchem Ireland Ltd., Naas, Ireland). Cows were administered antibiotic as a prophylactic $(500 \mathrm{mg}$ of ceftiofur hydrochloride; Excenel RTU; Pfizer Animal Health, Dublin, Ireland).

On d 10, frequent blood samples were collected via jugular catheter at $-60,-45,-30,-15,0,15,30,45$, $60,90,120,180,240,300,360,420,540$, and $660 \mathrm{~min}$ relative to removal of both CIDR (0 $\mathrm{min})$ to measure the half-life and MCR of P4. Catheter patency was maintained by flushing with $1 \mathrm{~mL}$ of heparinized sterile saline after each sample collection.

RNA Extraction and cDNA Synthesis. Total RNA was extracted from liver tissue using a standard TRIzol-based method (Chomczynski and Sacchi, 1987). The tissue sample was weighed and $100 \mathrm{mg}$ was homogenized in $3 \mathrm{~mL}$ of TRI Reagent (Sigma-Aldrich, Dublin, Ireland) for $30 \mathrm{~s}$ at $6,000 \mathrm{rpm}$ using a Precellys 24 Dual bead beater with ceramic beads (Bertin Technologies, Montigny-le-Bretonneux, France). The homogenate was removed to sterile Eppendorf tubes (Eppendorf UK Ltd., Stevenage, UK) and incubated at room temperature for $5 \mathrm{~min}$; $300 \mu \mathrm{L}$ of bromochloropropane (Sigma-Aldrich) was added, and samples were vortexed and incubated at room temperature for $3 \mathrm{~min}$, and then centrifuged at 12,000 $\times \mathrm{g}$ for $10 \mathrm{~min}$ at $4^{\circ} \mathrm{C}$. The supernatant was removed to new sterile tubes. Isopropanol was added at 0.6 times the volume of supernatant and vortexed and centrifuged at 12,000 $\times g$ for $10 \mathrm{~min}$ at $4^{\circ} \mathrm{C}$ to pellet the RNA. The supernatant was discarded and the pellet was washed twice in $99 \%$ ethanol (Sigma-Aldrich) with centrifugation at
$7,500 \times g$ for $5 \min$ at $4^{\circ} \mathrm{C}$. The RNA was resuspended in $35 \mu \mathrm{L}$ of nuclease-free water (Sigma-Aldrich). A kitbased protocol (RNeasy; Qiagen Ltd., Crawley, UK) was used to clean the total RNA, removing the fraction below $200 \mathrm{bp}$ as well as any DNA. The RNA quality and concentration was determined using a NanoDrop ND-1000 spectrophotometer (NanoDrop Technologies LLC, Wilmington, DE) and a 2100 Bioanalyzer system (Agilent Technologies UK Ltd., Wokingham, UK) using the RNA Nano Chip. The 260:280 nm absorbance ratio ranged between 1.92 and 2.18 for all samples. The RNA integrity number and $28 \mathrm{~S}: 18 \mathrm{~S}$ ratio ranged from 7.1 to 8.8 and 1.1 to 1.5 , respectively. Subsequently, $500 \mathrm{ng}$ of RNA was reverse transcribed to cDNA using the High-Capacity cDNA Reverse Transcription kit (Applied Biosystems Inc., Foster city, CA) per the manufacturer's instructions to synthesize cDNA in a $20-\mu \mathrm{L}$ reaction, diluted to $1 \mathrm{ng} / \mu \mathrm{L}$ of RNA equivalents with water, and stored at $-20^{\circ} \mathrm{C}$.

Primer Design and Reference Gene Selection. Primers were designed to span exon-exon junctions where possible, and PCR product size was restricted to between 50 and 155 nucleotides, using the NCBI/ Primer-BLAST tool (http://www.ncbi.nlm.nih.gov/ tools/primer-blast/). All primers were manufactured by Eurofins MWG (Ebersberg, Germany). The expression of $\beta$-actin $(A C T B)$, ribosomal protein L19 (RPL19), peptidylprolyl isomerase A (cyclophilin A) (PPIA), and mitogen-activated protein kinase $3(M A P K 3)$ were investigated as candidate reference genes on a subset of 12 samples that were representative of the 2 genotypes and their sires. The geNorm application within the Biogazelle qbase ${ }^{+}$software program (http://www. qbaseplus.com; Biogazelle, Ghent, Belgium) determined that PPIA and RPL19 combined were the most stably expressed reference genes, with an expression stability (M) value of 0.24 . The expected product sizes for all primers were confirmed by gel electrophoresis.

Real-Time Quantitative PCR. All real-time quantitative PCR reactions were performed in a 20.0$\mu \mathrm{L}$ reaction using $5 \mu \mathrm{L}(5 \mathrm{ng})$ of $\mathrm{cDNA}, 10 \mu \mathrm{L}$ of SYBR MasterMix (Bioline Reagents Ltd., London, UK), and $1.2 \mu \mathrm{L}$ of a $300 \mathrm{n} M$ solution of both forward and reverse primers on clear 96-well plates (FrameStar; 4titude Ltd., Wotton, UK). All samples were measured in duplicate. Primer efficiencies for each target were determined using a 1-in-4 serial dilution over 7 points and were shown to lie between $90 \%$ and $110 \%$; nontemplate controls and minus reverse transcriptase controls were also included for each target. The primer sequences used in the real-time quantitative PCR are shown in Table 2.

All reactions were run on a 7500 Real-Time PCR machine (Applied Biosystems Inc.) with the following cycling conditions: $50^{\circ} \mathrm{C}$ for $2 \mathrm{~min}, 95^{\circ} \mathrm{C}$ for $10 \mathrm{~min}$, 
Table 2. Primer sequences used in real-time quantitative PCR

\begin{tabular}{|c|c|c|c|}
\hline Gene name $^{1}$ & Primer sequence $5^{\prime}-3^{\prime}$ & $\begin{array}{l}\text { Product } \\
\text { size (bp) }\end{array}$ & $\begin{array}{l}\text { GenBank accession } \\
\text { number }\end{array}$ \\
\hline$A K R 1 C 1$ & $\begin{array}{l}\text { Forward: CCCAAAAGCACAAGCAGACCCCA } \\
\text { Reverse: GCCCTCTGCCCACAGTCTCACT }\end{array}$ & 144 & NM_001206787.1 \\
\hline$A K R 1 C 3$ & $\begin{array}{l}\text { Forward: TTCTTGTTGGTGTCGGTCACCCT } \\
\text { Reverse: TCACCACCCCACAGAAGTAAAGAGT }\end{array}$ & 99 & NM_001038584.1 \\
\hline$A K R 1 C 4$ & $\begin{array}{l}\text { Forward: GCTATTACTGGGTGTTGGTCACCCT } \\
\text { Reverse: ATCCTCTTCACAGCCCTAGAAGCA }\end{array}$ & 112 & NM_181027.2 \\
\hline CYР2C19 & $\begin{array}{l}\text { Forward: TGACCTTGTCCCCAGCAGTATGC } \\
\text { Reverse: TGACTGTGCCCTTGGGAATGAGGT }\end{array}$ & 83 & NM_001109792.1 \\
\hline СYРЗА 5 & $\begin{array}{l}\text { Forward: GAATTGGCCACTCACCCTGATGTCC } \\
\text { Reverse: CATCATAGGTCGGAGGCGCCTTAT }\end{array}$ & 88 & NM_001075888.1 \\
\hline PPIA & $\begin{array}{l}\text { Forward: TCCATGGCAAATGCTGGCCCC } \\
\text { Reverse: ACGTGCTTGCCATCCAACCACT }\end{array}$ & 86 & NM_178320.2 \\
\hline$M A P K 3$ & $\begin{array}{l}\text { Forward: GACCCAACGGATGAGCCAG } \\
\text { Reverse: CACCCCAGGCTGGAAGC }\end{array}$ & 123 & NM_001110018.1 \\
\hline$A C T B$ & $\begin{array}{l}\text { Forward: CGCCATGGATGATGATATTGC } \\
\text { Reverse: AAGCCGGCCTTGCACAT }\end{array}$ & 66 & NM_173979.3 \\
\hline RPL19 & $\begin{array}{l}\text { Forward: GAAAGGCAGGCATATGGGTA } \\
\text { Reverse: TCATCCTCCTCATCCAGGTT }\end{array}$ & 86 & NM_001040516.1 \\
\hline
\end{tabular}

${ }^{1} A K R 1 C 1=$ aldo-keto reductase family 1 , member $\mathrm{C} 1 ; A K R 1 C 3=$ aldo-keto reductase family 1 , member $\mathrm{C} 3$; $A K R 1 C 4=$ aldo-keto reductase family 1 , member C4; CYP2C19 = cytochrome P450, family 2, subfamily C, polypeptide 19; CYP3A5 = cytochrome P450, family 3, subfamily A; PPIA = peptidylprolyl isomerase A (cyclophilin A); $M A P K 3=$ mitogen-activated protein kinase 3; $A C T B=\beta$-actin; RPL19 = ribosomal protein L19.

40 cycles of $95^{\circ} \mathrm{C}$ for $15 \mathrm{~s}$ and $60^{\circ} \mathrm{C}$ for $1 \mathrm{~min}$, and then $95^{\circ} \mathrm{C}$ for $15 \mathrm{~s}, 60^{\circ} \mathrm{C}$ for $1 \mathrm{~min}$, and $95^{\circ} \mathrm{C}$ for 15 $\mathrm{s}$ to create a dissociation curve, which was examined to ensure that amplification was specific to the target gene. Relative gene expression [calibrated, normalized relative quantity (CNRQ)] values were determined using the qbase ${ }^{+}$software package.

\section{Study 2}

Feed and Management System. The objective of this study was to determine the temporal pattern of CL blood flow and circulating P4 concentrations during the estrous cycle. The study was undertaken at Teagasc Moorepark from January 2012 to December 2012. Mean calving dates were February 17 (SD: $\pm 19.7 \mathrm{~d}$ ) and February 24 (SD: $\pm 24.7 \mathrm{~d}$ ) for the Fert+ and Fert- cows, respectively. Following parturition, cows were housed in a freestall barn and were fed a TMR ad libitum plus $6 \mathrm{~kg}$ of dairy concentrate per day at the a.m. and p.m. milkings. Diet ingredients were sampled weekly and composited monthly for analysis. The ingredient and nutrient composition of the diets are outlined in Table 3. Cows were turned out to grass on March 26, 2012, and managed as 1 herd in a rotational grazing system. Cows grazed a predominantly perennial ryegrass (Lolium perenne L.) sward with fresh pasture allocated daily. The mean daily herbage allowance was $14.5 \pm 1.3$ $\mathrm{kg}$ of $\mathrm{DM} /$ cow per day, which was supplemented with $3.2 \pm 0.2 \mathrm{~kg} / \mathrm{cow}$ per day of lactating cow concentrate fed at the a.m. and p.m. milkings. Milk and BCS measurements were collected as described for study 1 .
Ovulation Synchronization. Cows were enrolled on the same ovulation synchronization protocol used in study 1 . The mean days postpartum $( \pm \mathrm{SD})$ when cows were enrolled in the protocol was $56 \pm 5.7$ (range: 45-67) and $54 \pm 9.1$ (range: 34-63) for the Fert+ and Fert- cows, respectively.

Blood Sampling. Blood samples were collected once daily on $\mathrm{d}-3,-2,-1,0,1,2$, and 3 (a.m. milking) and twice daily on d 4, 5, 6, 7, 8, 9, 10, 11, 12 (at 12-h intervals), and 13 (once, after the a.m. milking) relative to synchronized estrus (d 0) and processed as described in study 1 .

Ovarian Ultrasonography. Transrectal ultrasound examinations of both ovaries were carried out on d 0 , 4, 7, 10, and 13 using a Voluson i ultrasound machine equipped with a $12-\mathrm{MHz}$ linear array probe. Three images of follicles $\geq 15 \mathrm{~mm}$ on $\mathrm{d} 0$ and of the CL on $\mathrm{d} 4,7$, 10 , and 13 were captured in B-mode and power Doppler mode as described in study 1.

Blood Sample Analysis. Circulating P4 concentrations were determined in samples collected from $\mathrm{d} 1$ to 9 after synchronized estrus and from -60 to $660 \mathrm{~min}$ relative to CIDR removal during study 1 , and in samples collected from d 1 to 13 after synchronized estrus during study 2, using a commercially available solid-phase RIA (Coat-A-Count Progesterone; Diagnostic Products Corp., Los Angeles, CA). The inter- and intraassay coefficients of variation for study 1 were 17.2 and $11.1 \%$, 10.0 and $8.3 \%$, and 9.4 and $6.9 \%$ for the low-, medium-, and high-P4 pools respectively. The inter- and intraassay coefficients of variation for study 2 were 12.8 and $11.7 \%, 9.9$ and $7.0 \%$, and 5.2 and $6.2 \%$ for the low-, 
Table 3. Ingredient and nutrient composition of the lactating cow diet

\begin{tabular}{l} 
Composition \\
\hline Lactating cow diet (\% of DM) \\
Maize silage \\
Grass silage \\
Parlor concentrate \\
Soybean meal \\
Concentrate ingredient (\% of fresh matter) \\
Wheat \\
Soybean \\
Rapeseed extract \\
Sunflower seed extract \\
Palm kernel meal \\
Milk solids \\
Maize gluten \\
Citrus pulp \\
Soybean hulls \\
Palm oil \\
Oat feed \\
Minerals ${ }^{1}$ \\
Concentrate nutrient composition \\
DM (g/kg) \\
Net energy (UFL/kg of DM) \\
Ash (g/kg of DM) \\
CP (g/kg of DM) \\
NDF (g/kg of DM)
\end{tabular}

${ }^{1}$ Vitamin and mineral mix: $229 \mathrm{~g}$ of $\mathrm{Ca} / \mathrm{kg}, 100 \mathrm{~g}$ of Na/kg, $70 \mathrm{~g}$ of $\mathrm{P} /$ $\mathrm{kg}, 5 \mathrm{~g}$ of $\mathrm{Mg} / \mathrm{kg}, 4,500 \mathrm{mg}$ of $\mathrm{Zn} / \mathrm{kg}, 3,000 \mathrm{mg}$ of $\mathrm{Cu} / \mathrm{kg}, 1,500 \mathrm{mg}$ of $\mathrm{Mn} / \mathrm{kg}, 500 \mathrm{mg}$ of $\mathrm{I} / \mathrm{kg}, 400 \mathrm{mg} / \mathrm{kg}$ of Bioplex $\mathrm{Cu}$ (Alltech Inc., Nicholasville, KY), $400 \mathrm{mg}$ of Bioplex Zn/kg, $99 \mathrm{mg}$ of $\mathrm{Co} / \mathrm{kg}, 37 \mathrm{mg}$ of $\mathrm{Se} / \mathrm{kg}, 375,000 \mathrm{IU}$ of vitamin $\mathrm{A} / \mathrm{kg}, 100,000 \mathrm{IU}$ of vitamin $\mathrm{D}_{3} / \mathrm{kg}$, $1,250 \mathrm{mg}$ of vitamin $\mathrm{E} / \mathrm{kg}$, and $200 \mathrm{mg}$ of vitamin $\mathrm{B}_{12} / \mathrm{kg}$.

medium-, and high-P4 pools respectively. Circulating E2 concentrations were determined in samples collected on $\mathrm{d}-3,-2,-1$, and 0 in the 2 studies by RIA following extraction using E2 MAIA kits (Bio-Stat Diagnostic Systems Ltd., Stockport, UK). Peak circulating E2 concentration and day of peak were determined for each cow. The inter- and intraassay coefficients of variation were 15.2 and $23.0 \%, 16.5$ and $11.2 \%$, and 5.3 and $10.4 \%$ assay for the low-, medium-, and highE2 pools respectively. Circulating insulin and IGF-1 concentrations were determined in samples collected on d 0,7 , and 9 during study 1 and d 0 and 13 during study 2 . Insulin concentrations were determined by solid-phase ${ }^{125}$ I RIA (Coat-A-Count Insulin; Diagnostic Products Corp.). The inter- and intraassay coefficients of variation were 7.8 and $13.5 \%$, respectively. Concentrations of IGF-1 were determined using a validated double antibody RIA, following ethanol:acetone:acetic acid extraction (Enright et al., 1989). The inter- and intraassay coefficients of variation were 2.7 and $12.1 \%$, respectively. Both genotypes were represented equally in each hormone assay, and all samples for each cow were completed within 1 assay.

Ultrasound Image Analysis. The diameter of the follicle measured on d 0 in study 1 was calculated as the mean of the cross-sectional height and width. The diameter of the follicle and CL scanned with the Volu- son i ultrasound machine were calculated as the mean of 3 cross-sectional diameters measured from each image. The CL volume was calculated using the following formula: volume $=4 / 3 \times \pi \times\left(0.5 \times\right.$ diameter $^{3}$ and the volume of luteal cavities were calculated and subtracted if present. Luteal tissue area was calculated using the following formula: area $=\pi \times(0.5 \times$ diameter $)^{2}$ and the area of luteal cavities were calculated and subtracted if present. Power Doppler images of the CL were analyzed using the computer program Pixel Flux (version 1.0; Chameleon Software, Leipzig, Germany) to quantify the area (in $\mathrm{cm}^{2}$ ) of colored pixels within the CL, which is considered a semiquantitative measure of blood flow. Mean blood flow area (BFA) of each structure was calculated using the 3 images. Corpus luteum relative BFA (relBFA) was calculated as blood flow area/luteal tissue area.

Data Handling. Cows were deemed to have had a synchronized estrus if the preovulatory follicle measured on $\mathrm{d} 0$ resulted in CL formation and circulating $\mathrm{P} 4$ concentrations were $<0.7 \mathrm{ng} / \mathrm{mL}$ on $\mathrm{d} 1$ and $>1.1$ $\mathrm{ng} / \mathrm{mL}$ on $\mathrm{d} 7$. Twenty-eight cows were enrolled in study 1. Records of 6 cows were not included in the statistical analysis (1 Fert+ cow and 2 Fert- cows did not respond to the ovulation synchronization protocol based on P4 profiles and 1 Fert+ cow and 2 Fert- cows were diagnosed as having uterine infection on $\mathrm{d} 7$ ). Twenty-three cows were enrolled in study 2. Records of 2 Fert- cows were not included in the statistical analysis because they did not respond to the ovulation synchronization protocol based on P4 profiles. Daily measurements of milk yield were collapsed into average weekly yields. Milk production, DMI, BW, and BCS data collected during the 4 -wk period before and during both studies are reported. Data were checked for normality. In study 1, suitable Box-Cox transformations were identified to normalize the distribution of circulating E2 concentrations, $\mathrm{P} 4$ half-life, and mRNA abundance of aldo-keto reductase family 1 , member C1 (AKR1C1) and AKR1C4. In study 2, suitable BoxCox transformations were identified to normalize the distribution of follicle diameter, BFA, CL volume, and circulating E2 and P4 concentrations.

Statistical Analysis. All statistical analysis was performed using SAS (SAS Institute, 2006), with the exception that $\mathrm{R}$ software ( $\mathrm{R}$ Core Team, 2013) was used to generate the box plots. Nonlinear regression was used to calculate the parameter for rate of $\mathrm{P} 4$ decay for each cow by fitting parameter estimates from the first 60 min following removal of 2 CIDR devices to the following equation:

$$
f(t)=b \times e^{(c \times t)}
$$


where $\mathrm{t}=$ time, $\mathrm{b}=$ parameter for starting concentration of $\mathrm{P} 4$, and $\mathrm{c}=$ parameter for rate of decay.

Finally, P4 half-life and MCR were calculated using the following equations:

$$
\begin{aligned}
& \text { half-life }[\min =\ln (2) / c] ; \\
& \operatorname{MCR}(\% / \min )=c \times 100 .
\end{aligned}
$$

Mixed-model procedures were used to determine the effect of genotype on variables with repeated measures such as milk production, BW, BCS, DMI, reproductive hormone concentrations, and CL measurements (study 2 ). Fixed effects included genotype, time (minute or day or week) and their interactions. Parity, calving date, block, and their interactions with genotype were included initially but removed if not significant $(P>0.1)$. Cow nested within genotype was included as a random effect, time was included as a repeated effect, and a first-order autoregressive covariance structure was applied. Mixed-model procedures were used to determine the effect of genotype on variables without repeated measures. Genotype was included as a fixed effect. Parity, calving date, block and the interaction of parity with genotype were included initially but removed if not significant $(P>0.1)$. Cow nested within genotype was included as a random effect. The effect of genotype on day of peak circulating E2 concentrations was determined by one-way nonparametric test. Circulating P4 concentration data from d 3 to 7 of the estrous cycle in both study 1 and study 2 were combined, and the rate of increase in circulating $\mathrm{P} 4$ concentrations for each genotype was determined by regressing circulating $\mathrm{P} 4$ concentration against day.

\section{RESULTS}

\section{Study 1}

Milk Production and Animal Characteristics. The effect of genetic merit for fertility traits on DMI, BW, and milk yield is illustrated in Figure 1. Dry matter intake tended to be greater in Fert + cows than Fert - cows $(+0.79 \mathrm{~kg}$ of DM/d; $P=0.06)$. Milk yield (mean: $29.8 \mathrm{~kg} / \mathrm{d} ; P=0.98$ ), milk solids yield (mean: $2.28 \mathrm{~kg} / \mathrm{d} ; P=0.38$ ), BCS (mean: $2.75 \mathrm{U} ; P=0.37$ ), circulating insulin (mean: $3.21 \mu \mathrm{IU} / \mathrm{mL} ; P=0.49$ ), and IGF-1 concentrations (mean: $116.9 \mathrm{ng} / \mathrm{mL} ; P=0.13$ ) were similar in both genotypes.

Ovarian Characteristics and Reproductive Hormones. The effect of genetic merit for fertility traits on ovarian characteristics and reproductive hormones during study 1 is summarized in Table 4. The diameter of the preovulatory follicle was $9 \%$ greater in
Fert + cows than Fert - cows $(+1.44 \mathrm{~mm} ; P=0.04)$. No effect of genotype on CL volume $(P=0.12)$ was observed. The BFA of the CL was $42 \%$ greater in Fert+ cows compared with Fert- cows $\left(+0.64 \mathrm{~cm}^{2} ; P=0.03\right)$. The relBFA of the CL was similar in both genotypes $(P=0.7)$.

The profile of mean circulating E2 and P4 concentrations in Fert+ and Fert- cows is illustrated in Figure 2. A genotype $\times$ day interaction for circulating E2 concentrations was observed $(P=0.01)$, which arose primarily because of a robust preovulatory increase in circulating E2 concentrations on day -1 in Fert+ cows that was not evident in Fert- cows. As a result, peak circulating E2 concentration was greater in Fert+ cows than in Fert- cows $(+1.94 \mathrm{pg} / \mathrm{mL} ; P=0.007)$. Day of peak circulating E2 concentrations was similar in both genotypes (mean: $\mathrm{d}-1 ; P=0.94$ ). A genotype $\times$ day interaction for circulating $\mathrm{P} 4$ concentrations was observed $(P=0.03)$ because of a more rapid increase in Fert+ cows compared with Fert- cows.

P4 Metabolism. The effect of genotype on hepatic mRNA abundance of genes responsible for P4 catabolism is illustrated in Figure 3. The mRNA abundance of cytochrome P450, family 3, subfamily A (CYP3A) was greater in Fert- cows than Fert+ cows $(P=0.05)$, whereas the mRNA abundance of AKR1C1, AKR1C3, $A K R 1 C 4$, and cytochrome P450, family 2, subfamily C (CYP2C) was similar in both genotypes (all $P>0.2$ ). The profile of circulating $\mathrm{P} 4$ concentrations in Fert+ and Fert- cows during the P4 clearance study is illustrated in Figure 3. No effect of genotype on the half-life $(P=0.70)$ and MCR $(P=0.79)$ of $\mathrm{P} 4$ was detected following removal of the 2 CIDR (Table 5 ).

\section{Study 2}

Milk Production and Animal Characteristics. Milk yield (mean: $31.7 \mathrm{~kg} / \mathrm{d} ; P=0.81$ ), milk solids yield (mean: $2.30 \mathrm{~kg} / \mathrm{d} ; P=0.14$ ), BW (mean: $540 \mathrm{~kg}$; $P=0.16)$, and circulating insulin concentrations (3.23 $\mu \mathrm{IU} / \mathrm{mL} ; P=0.28)$ were similar in both genotypes. Body condition score (2.88 vs. $2.55 \mathrm{U} ; P=0.0002$ ) and circulating IGF-1 concentrations $(128.3 \pm 7.4$ vs. 95.6 $\pm 9.4 \mathrm{ng} / \mathrm{mL} ; P=0.05)$ were greater in Fert+ cows compared with Fert- cows.

Ovarian Characteristics and Reproductive Hormones. The effect of genetic merit for fertility traits on ovarian characteristics and reproductive hormones during study 2 is summarized in Table 6 . The diameter of the preovulatory follicle tended to be greater in Fert+ cows compared with Fert- cows $(P=0.09)$. Mean circulating E2 concentrations were $54 \%$ greater in Fert+ cows than in Fert- cows $(+0.48 \mathrm{pg} / \mathrm{mL} ; P=$ 0.02; Figure 4). Peak circulating E2 concentrations were 

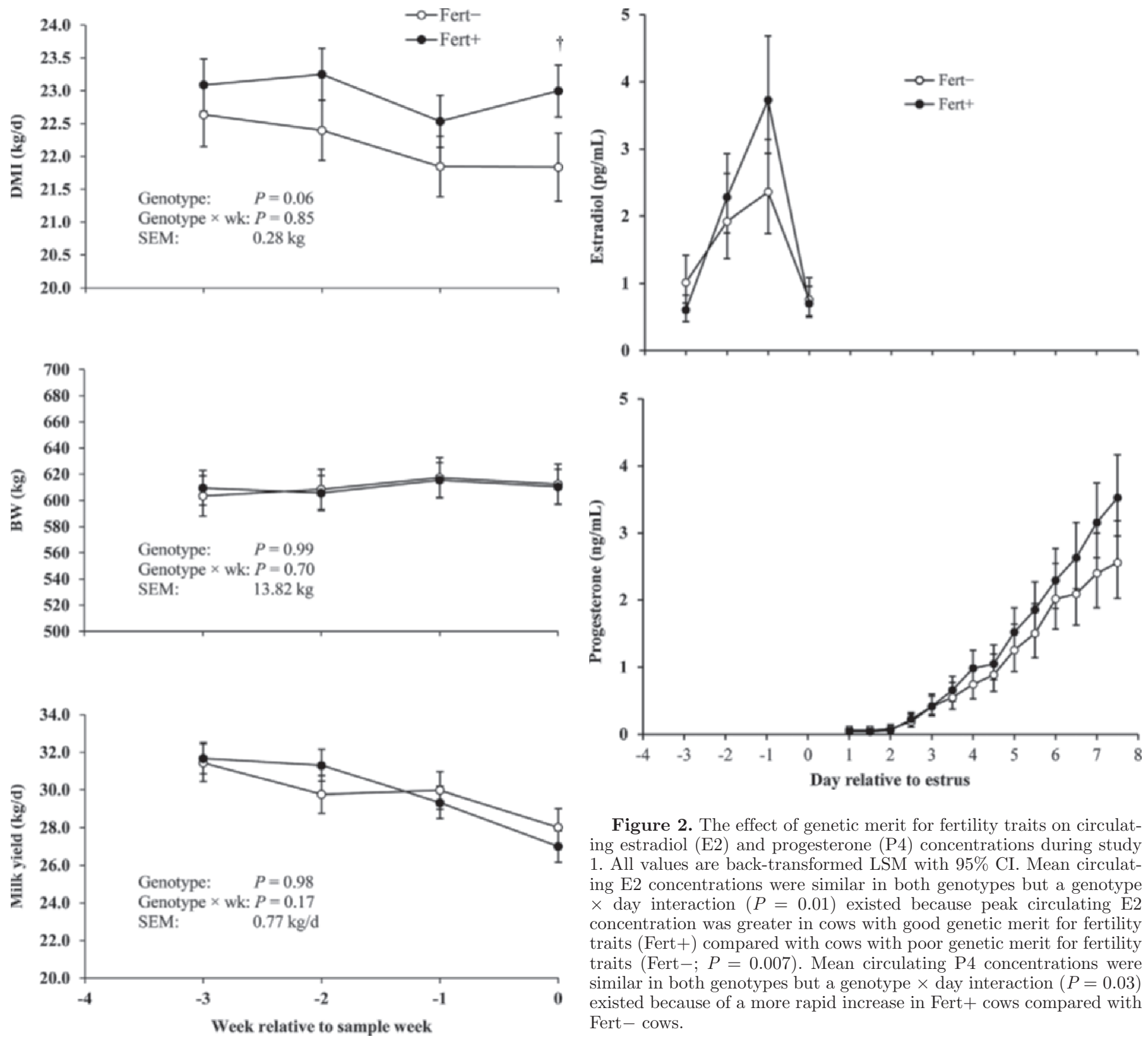

Figure 2. The effect of genetic merit for fertility traits on circulating estradiol (E2) and progesterone (P4) concentrations during study 1. All values are back-transformed LSM with $95 \%$ CI. Mean circulating E2 concentrations were similar in both genotypes but a genotype $\times$ day interaction $(P=0.01)$ existed because peak circulating E2 concentration was greater in cows with good genetic merit for fertility traits (Fert+) compared with cows with poor genetic merit for fertility traits (Fert-; $P=0.007$ ). Mean circulating P4 concentrations were similar in both genotypes but a genotype $\times$ day interaction $(P=0.03)$ existed because of a more rapid increase in Fert+ cows compared with Fert- cows.

Figure 1. The effect of genetic merit for fertility traits on DMI, BW, and milk yield during the $4 \mathrm{wk}$ before completion of the study. All values are LSM. Dry matter intake tended to be greater in cows with good genetic merit for fertility traits (Fert+) compared with cows with poor genetic merit for fertility traits (Fert-), whereas BW and milk yield were similar. $\dagger P \leq 0.1$.

$53 \%$ greater in Fert + cows than in Fert- cows $(+1.18$ $\mathrm{pg} / \mathrm{mL} ; P=0.01)$. Day of peak circulating E2 concentrations tended to be earlier in Fert- cows compared with Fert+ cows $(P=0.1)$. Corpus luteum volume tended to be $41 \%$ greater in Fert+ cows compared with Fert - cows $\left(+2,357.8 \mathrm{~mm}^{3} ; P=0.06\right)$, but no effect of genotype on CL BFA $(P=0.45)$ or relBFA $(P=0.12)$ was detected. Mean circulating $\mathrm{P} 4$ concentrations were

$79 \%$ greater in Fert+ cows than Fert- cows $(+1.67 \mathrm{ng} /$ $\mathrm{mL} ; P<0.0001$; Figures 4 and 5$)$. A genotype $\times$ day interaction $(P=0.0001)$ arose because of a more rapid increase in circulating P4 concentrations in Fert+ cows after d 6. Simple linear regression analysis indicated that circulating $\mathrm{P} 4$ concentrations increased by 0.79 $\mathrm{ng} / \mathrm{mL}$ per day and $0.52 \mathrm{ng} / \mathrm{mL}$ per day between $\mathrm{d} 3$ and 7 of the estrous cycle in Fert+ and Fert- cows, respectively:

Regression equation for Fert + cows $( \pm \mathrm{SEM})$ :

$\mathrm{P} 4=(0.79 \pm 0.03) \times$ day $-2.12 \pm 0.18 ; \mathrm{R}^{2}=0.71 ;$ 
Table 4. The effect of genetic merit for fertility traits on ovarian characteristics and reproductive hormones during study 1

\begin{tabular}{|c|c|c|c|c|c|}
\hline \multirow[b]{2}{*}{ Variable } & \multicolumn{2}{|c|}{ Genotype $^{1}$} & \multirow[b]{2}{*}{$\mathrm{SEM}^{2}$} & \multicolumn{2}{|c|}{$P$-value } \\
\hline & Fert+ & Fert- & & Genotype & $\begin{array}{l}\text { Genotype } \\
\times \text { day }\end{array}$ \\
\hline \multicolumn{6}{|l|}{ Preovulatory follicle } \\
\hline Diameter $(\mathrm{mm})$ & 17.23 & 15.79 & 0.45 & 0.04 & - \\
\hline \multicolumn{6}{|l|}{ Estradiol (pg/mL) } \\
\hline $\mathrm{d}-3$ to $0^{3}$ & $1.46(1.23-1.73)$ & $1.40(1.13-1.71)$ & - & 0.73 & 0.01 \\
\hline Peak & 4.26 & 2.32 & 0.41 & 0.0007 & - \\
\hline \multicolumn{6}{|l|}{ Corpus luteum ${ }^{4}$} \\
\hline Volume $\left(\mathrm{mm}^{3}\right)$ & $8,385.06$ & $6,786.77$ & 389.62 & 0.12 & - \\
\hline $\mathrm{BFA}\left(\mathrm{cm}^{2}\right)$ & 2.15 & 1.51 & 0.17 & 0.03 & - \\
\hline relBFA $(\%)$ & 55.0 & 52.2 & 4.7 & 0.68 & - \\
\hline $\begin{array}{l}\text { Progesterone }(\mathrm{ng} / \mathrm{mL}) \\
\text { d } 1 \text { to } 7.5^{3}\end{array}$ & $0.85(0.67-1.05)$ & $0.73(0.55-0.96)$ & - & 0.40 & 0.03 \\
\hline
\end{tabular}

${ }^{1}$ Fert $+=$ good-fertility cows; Fert $-=$ poor-fertility cows.

${ }^{2}$ Pooled SEM

${ }^{3}$ Data are presented as LSM with $95 \%$ CI in parentheses.

${ }^{4} \mathrm{BFA}=$ blood flow area; relBFA $=$ relative $\mathrm{BFA}$.

Regression equation for Fert- cows $( \pm \mathrm{SEM})$ :

$$
\mathrm{P} 4=(0.52 \pm 0.04) \times \text { day }-1.26 \pm 0.21 ; \mathrm{R}^{2}=0.54 .
$$

\section{DISCUSSION}

The Fert+ cows had greater circulating P4 concentrations and greater CL volume compared with Fert- cows. The P4 synthetic capacity of the CL was the primary factor affecting circulating $\mathrm{P} 4$ concentrations, as no effect existed of genotype on $\mathrm{P} 4$ clearance or on the factors that affect $\mathrm{P} 4$ clearance (i.e., milk production, DMI, and hepatic mRNA abundance of P4 catabolic genes). Volume was the primary factor affecting P4 synthetic capacity of the CL, as no effect of genotype on CL BFA existed. Our results imply that greater preovulatory follicle diameter and greater peak E2 concentrations in Fert+ cows compared with Fertcows may have been associated with subsequent CL volume and $\mathrm{P} 4$ synthetic capacity.

\section{Preovulatory Follicle Characteristics and Circulating E2 Concentrations}

Our results indicate that preovulatory follicle diameter and preovulatory circulating E2 concentrations are important fertility traits. The Fert+ cows had greater peak circulating E2 concentrations $(\mathrm{d}-1)$ compared with Fert- cows. This may be explained by greater preovulatory follicle diameter on the day of presumptive estrus (significantly greater in study 1 and numerically greater in study 2). Circulating E2 concentrations must reach the threshold required by the surge center of the hypothalamus to release $\mathrm{GnRH}$, thereby facilitating the surge release of $\mathrm{LH}$ from the pituitary to initiate the cascade of events required for ovulation (Senger, 1997). Greater circulating preovulatory E2 concentrations have been reported in heifers compared with lactating cows (Sartori et al., 2004), and in dairy cows that subsequently became pregnant compared with dairy cows that did not (Lopes et al., 2007). Greater preovulatory follicle diameter has been reported in heifers (Siddiqui et al., 2009) and cows (Lopes et al., 2007) that subsequently became pregnant compared with those that did not. In addition, Stevenson et al. (2008) reported a positive correlation between the diameter of the ovulatory follicle at the time of CIDR removal and $\mathrm{PGF}_{2 \alpha}$ administration during a TAI protocol and circulating P4 concentrations $9 \mathrm{~d}$ later in heifers.

\section{Circulating P4 Concentrations}

The results of studies 1 and 2, combined with the results of Cummins et al. (2012b), provide strong evidence that superior genetic merit for fertility traits is associated with greater circulating $\mathrm{P} 4$ concentrations in lactating dairy cows. The P4 profiles from study 1 and study 2 indicate 2 clear characteristics. First, in keeping with our previous findings (Cummins et al., 2012b), mean circulating $\mathrm{P} 4$ concentrations were greater in Fert + cows compared with Fert- cows. Second, the interaction between genotype and time in both studies indicates that Fert+ cows have a more rapid postovulatory increase in circulating $\mathrm{P} 4$ concentrations compared with Fert- cows. Simple linear regression equations indicated that the rate of increase in $\mathrm{P} 4$ between $\mathrm{d} 3$ and 7 was $52 \%$ greater in Fert+ cows compared with Fertcows. Although the difference was smaller than in the current study, Walker et al., (2012) reported greater 
Table 5. The effect of genetic merit for fertility traits on progesterone (P4) half-life and metabolic clearance rate $(\mathrm{MCR})$

\begin{tabular}{|c|c|c|c|c|}
\hline \multirow[b]{2}{*}{ Variable } & \multicolumn{2}{|c|}{ Genotype $^{1}$} & \multirow[b]{2}{*}{$\mathrm{SEM}^{2}$} & \multirow[b]{2}{*}{$P$-value } \\
\hline & Fert+ & Fert- & & \\
\hline P4 MCR $(\% / \min )$ & 2.19 & 2.08 & 0.2 & 0.7 \\
\hline P4 half-life ${ }^{3}(\mathrm{~min})$ & $31.37(26.77-38.16)$ & $32.48(26.92-41.37)$ & - & 0.79 \\
\hline
\end{tabular}

circulating P4 concentrations in cows with New Zealand ancestry (good fertility) compared with cows with North American ancestry (poor fertility). It is clear that circulating P4 concentrations during the prebreeding and postbreeding periods are important fertility traits. These findings are supported by data from several studies that indicated that supplemental P4 improved conception rates (Macmillan and Peterson, 1993; Cunha et al., 2008; Herlihy et al., 2011; Colazo et al., 2013), synchrony of ovulation (Herlihy et al., 2011; Colazo et al., 2013), and reduced pregnancy loss between d 30 to 60 (Cunha et al., 2008; Colazo et al., 2013; Herlihy et al., 2013). Consistent with these results, improved fertility in lactating dairy cows was achieved by the use of a CIDR between d 3.5 to 10 postbreeding (Larson et al., 2007) and by human chorionic gonadotropin (hCG) on d 5 postbreeding (Nascimento et al., 2013a). However, other studies have reported no improvement in pregnancy rates (Lonergan, 2011). The success of P4 supplementation, or administration of $\mathrm{GnRH}$ or hCG may be dependent on the timing of the treatment and may only be beneficial in cows with low circulating $\mathrm{P} 4$ concentrations (Lonergan, 2011), as low circulating P4 concentrations from d 6 to 8 has been associated with negative pregnancy status following diagnosis on d 29 after AI (Lopes et al., 2007).

Greater circulating P4 concentrations in nulliparous Holstein heifers compared with lactating Holstein dairy cows is a likely mediator of superior fertility in heifers (Sartori et al., 2004; Wolfenson et al., 2004; Rizos et al., 2010). Nascimento et al. (2013b) evaluated the effectiveness of CIDR, hCG, and CIDR plus hCG treatments from $\mathrm{d} 5$ postestrus at raising circulating $\mathrm{P} 4$ concentrations in lactating dairy cows. Only cows receiving the CIDR plus hCG treatment achieved circulating P4 concentrations similar to those in heifers. Circulating P4 concentrations on d 13 of the estrous cycle in Fert+ cows in the current study were similar to cows treated with hCG, whereas Fert- cows achieved circulating P4 concentrations similar to control cows that received no treatment in the study reported by Nascimento et al. (2013b). These results indicate the important role of genetic selection for fertility traits in improving circulating P4 concentrations in lactating dairy cows. It

Table 6. The effect of genetic merit for fertility traits on ovarian characteristics during study 2

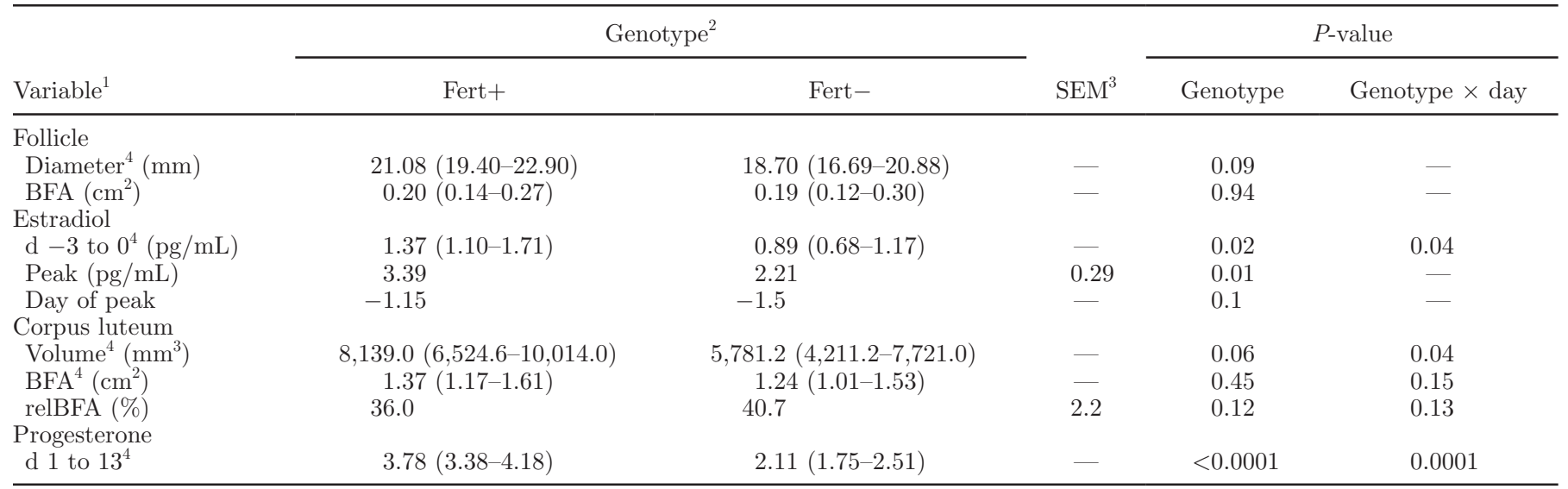

${ }^{1} \mathrm{BFA}=$ blood flow area; relBFA $=$ relative BFA.

${ }^{2}$ Fert $+=$ good-fertility cows; Fert $-=$ poor-fertility cows.

${ }^{3}$ Pooled SEM.

${ }^{4}$ Data are presented as LSM with $95 \%$ CI in parentheses. 
would be interesting to examine the conception rate response if circulating $\mathrm{P} 4$ concentrations in Fert- cows were increased to be similar to Fert+ cows.

\section{Characteristics}

Progesterone secretion is determined by the volume and blood flow of the CL, the metabolic rate of the luteal cells, and stage of the estrous cycle. We assessed CL function based on volume, BFA, and relBFA using transrectal ultrasonography. Although several authors reported that positive associations between CL size and circulating P4 concentrations depended on stage of the estrous cycle (Mann, 2009; Lüttgenau et al., 2011; Rizos et al., 2012), Herzog et al. (2010) reported that CL BFA was a better indicator of CL function than size during d 7 to 14 of the estrous cycle. During this period, circulating $\mathrm{P} 4$ concentrations and BFA doubled, whereas CL area increased only by $25 \%$. However, Lüttgenau et al. (2011) reported no correlation between BFA and circulating P4 concentrations during the mid-luteal phase in a subsequent study by the same group. As a result, Lüttgenau et al. (2011) suggested relBFA as a more relevant assessment of CL function by accounting
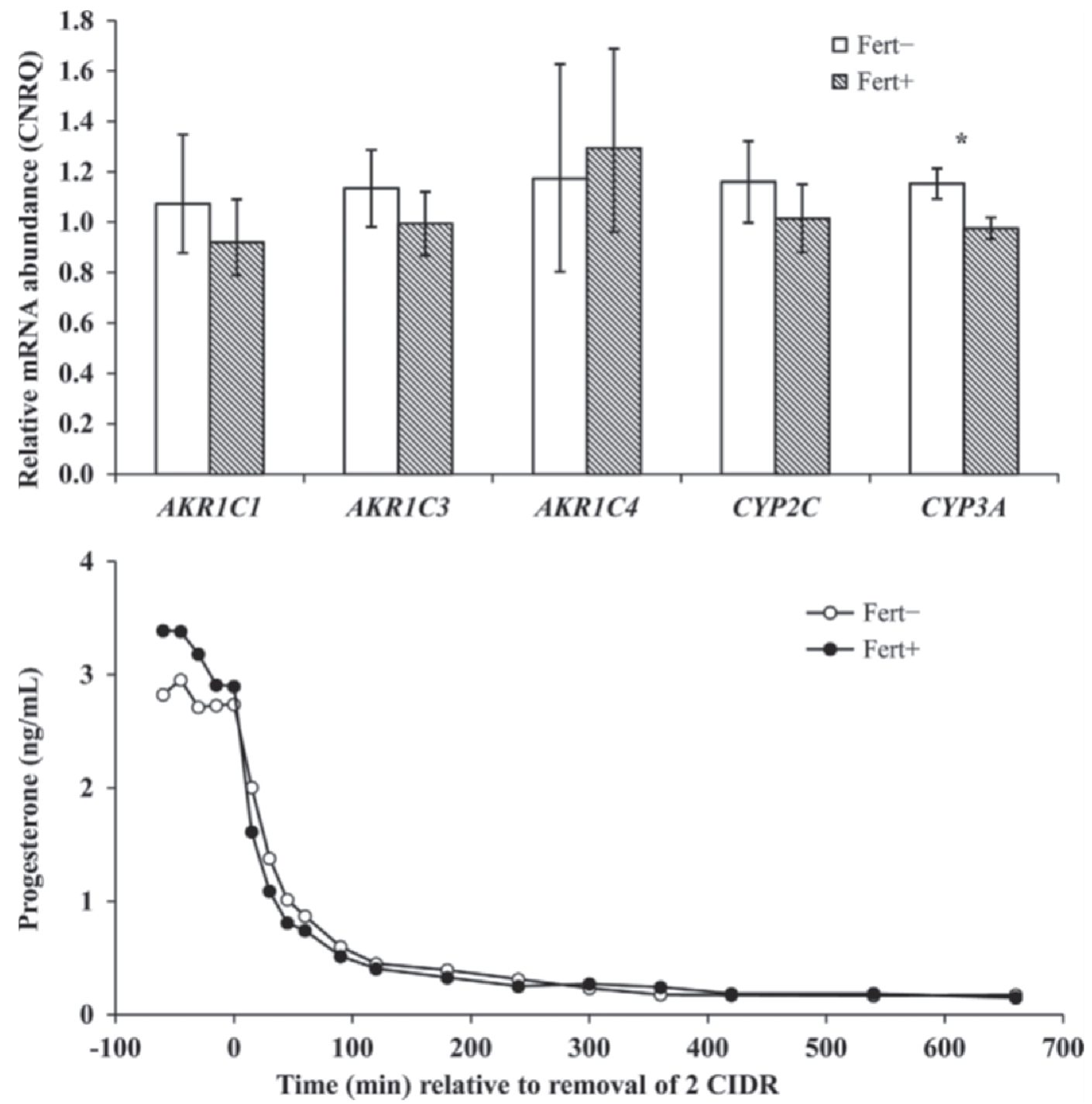

Figure 3. Top: the effect of genetic merit for fertility traits on hepatic mRNA abundance of candidate genes involved in progesterone (P4) metabolism. The mRNA abundance of cytochrome P450, family 3, subfamily A (CYP3A) was greater in cows with poor genetic merit for fertility traits (Fert-) compared with cows with good genetic merit for fertility traits (Fert+) but the mRNA abundance of aldo-keto reductase family 1, member C1 (AKR1C1), AKR1C3, AKR1C4, and cytochrome P450, family 2, subfamily C (CYP2C) was similar. Data are presented as LSM with 95\% CI. Bottom: circulating P4 concentrations in Fert+ and Fert- cows from -60 min to 660 min relative to removal of 2 controlled internal drug release (CIDR) devices. $\mathrm{CNRQ}=$ calibrated, normalized relative quantity values. 

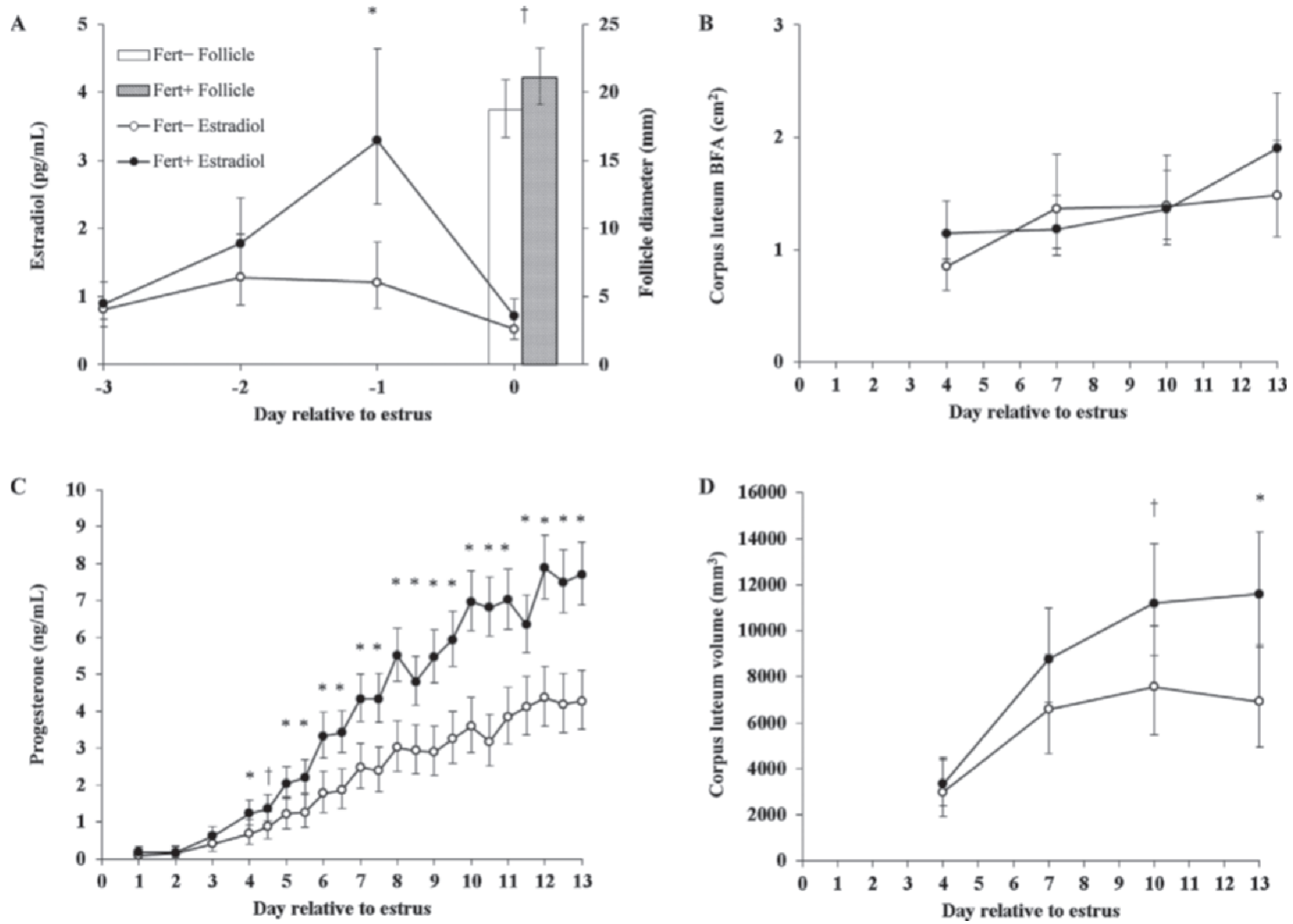

Figure 4. The effect of genetic merit for fertility traits on reproductive hormones, follicle diameter and corpus luteum (CL) characteristics during study 2 . Values are back-transformed LSM with $95 \%$ CI. ${ }^{*} P \leq 0.05 ; \dagger P \leq 0.1$. (A) Follicle diameter tended to be greater in cows with good genetic merit for fertility traits (Fert+) compared with cows with poor genetic merit for fertility traits (Fert-; $P=0.09)$. Mean circulating estradiol (E2) concentrations were greater in Fert + cows compared with Fert- cows $(P=0.02)$. A genotype $\times$ day interaction $(P=0.04)$ existed because peak circulating E2 concentrations were greater in Fert+ cows compared with Fert- cows $(P=0.01)$. (B) No effect of genotype on CL blood flow area (BFA; $P=0.45)$ was detected. $(\mathrm{C})$ Mean circulating progesterone (P4) concentrations were greater in Fert+ cows compared with Fert - cows $(P<0.0001)$ and a genotype $\times$ day interaction $(P=0.0001)$ existed because of a more rapid increase in Fert + cows compared with Fert- cows. (D) The CL volume tended to be greater in Fert+ cows compared with Fert- cows $(P=0.06)$.

for CL size. In a review of their studies, Bollwein et al. (2012) concluded that the correlation between BFA and circulating $\mathrm{P} 4$ concentrations reported by Herzog et al. (2010) was due to the fact that both measurements were closely associated with CL size. In study 1 of the current study, based on ultrasound measurements at a single time point on $\mathrm{d} 7$ of the estrous cycle, CL volume was numerically greater and BFA was significantly greater in Fert+ cows compared with Fert- cows. In study 2, employing a more thorough assessment, based on ultrasound measures at 4 time points, mean CL volume tended to be greater in Fert+ cows compared with Fert- cows but BFA was not affected by genotype. The relBFA was not affected by genotype in either study.
Taken together, our results indicate that CL volume rather than blood flow is the major factor determining CL P4 synthetic capacity, in agreement with Lüttgenau et al. (2011).

\section{P4 Clearance}

The removal of $\mathrm{P} 4$ from circulation is determined by the rate of blood flow through the liver and the activity of liver enzymes with P4 catabolic activity. Increased liver blood flow due to greater DMI (Sangsritavong et al., 2002; Reynolds et al., 2003) and the associated increase in liver steroid clearance has been implicated as a potential disruptor of reproductive events in high- 


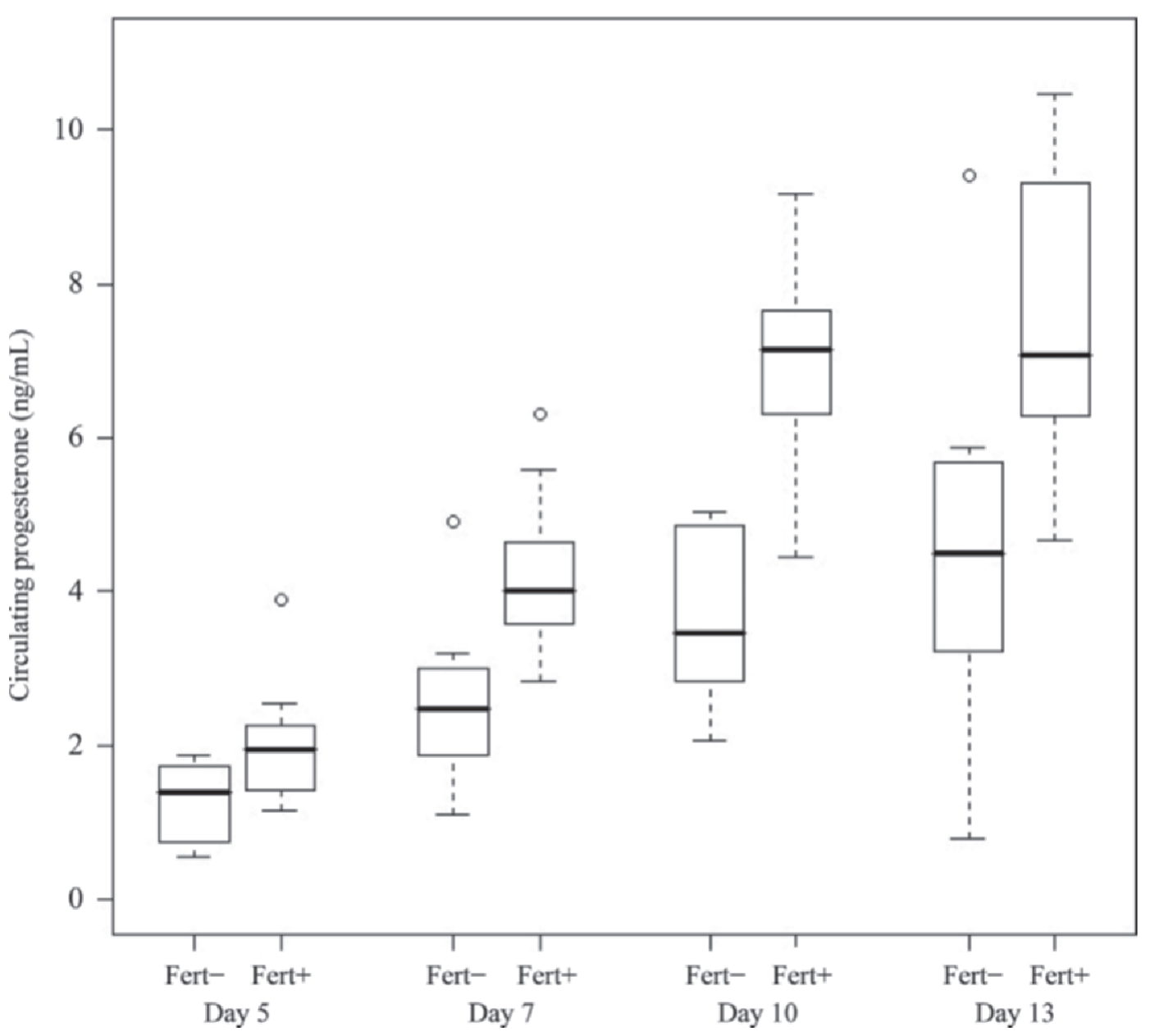

Figure 5. Box plots depicting circulating progesterone (P4) concentration quartiles from study 2 during d 5, 7, 10, and 13 of the estrous cycle in cows with good genetic merit for fertility traits (Fert+) and those with poor genetic merit for fertility traits (Fert-). The interquartile range and median of the data are represented by the box and horizontal line, respectively. The maximum and minimum values are represented by the whiskers. Single data points represent outliers in the data. Circulating P4 concentrations were significantly greater in Fert+ cows compared with Fert - cows on d $5(1.98$ vs. $1.27 \mathrm{ng} / \mathrm{mL} ; \mathrm{SEM}=0.21 ; P=0.03), 7(4.42$ vs. $2.59 ; \mathrm{SEM}=0.28 ; P=0.0002), 10(7.01$ vs. $3.66 ; \mathrm{SEM}=0.34 ; P$ $<0.0001)$, and 13 (7.96 vs. $4.63 ; \mathrm{SEM}=0.58 ; P=0.0007)$ of the estrous cycle.

producing dairy cows. Sangsritavong et al. (2002), Lemley et al. (2010a), and Hutchinson et al. (2012) have reported that it is possible to alter $\mathrm{P} 4$ clearance through dietary manipulation. The major genes responsible for P4 catabolism in the liver belong to the cytochrome P450 family (Murray, 1991, 1992). These are mixed-function monooxygenases that inactivate $\mathrm{P} 4$ by hydroxylation to hydroxyprogesterone. In addition, the aldo-keto reductase family inactivate $\mathrm{P} 4$ by reduction to hydroxyprogesterone (Penning et al., 2000). Although no effect of genotype on mRNA abundance of AKR1C1, AKR1C3, AKR1C4, and CYP2C was detected, Fert- cows had greater mRNA abundance of CYP3A. Downregulation of CYP3A or reduced activity of its enzyme in response to elevated circulating insulin has been previously reported (Lemley et al., 2008, 2010a,b). No differences existed in circulating insulin concentrations between Fert+ and Fert- cows at the time of the liver biopsy in the current study. The lack of an effect of genotype on the MCR and half-life of $\mathrm{P} 4$ seems reasonable, considering that 4 of the 5 candidate genes were not differentially expressed. In addition, milk yield was similar between genotypes in both studies. Although the Fert+ cows tended to have greater DMI compared with the Fert- cows, the difference equated to only $3.6 \%$, whereas Sangsritavong et al. (2002) maintained a difference of $200 \%$ in DMI between treatment groups in their study.

\section{CONCLUSIONS}

Insufficient circulating $\mathrm{P} 4$ concentrations have been implicated as a major cause of poor fertility in lactating dairy cows. The naturally occurring differences in 
circulating $\mathrm{P} 4$ concentrations between Fert+ and Fertcows provided us with a unique opportunity to examine the factors that affect circulating P4 concentrations without the need to artificially manipulate their diet or hormone profiles. The results of our studies indicate that (1) Fert+ cows had greater circulating P4 concentrations during the estrous cycle than Fert- cows, (2) these differences were due to greater CL volume rather than differences in P4 clearance, and (3) genetic selection for high circulating $\mathrm{P} 4$ concentrations is possible without antagonizing milk production.

\section{ACKNOWLEDGMENTS}

The authors thank J. P. Murphy and F. Coughlan (both from the Moorepark farm, Fermoy, Co. Cork, Ireland) and the Moorepark farm staff for management and care of the cows enrolled in this study. The authors thank Bruce Moran (Animal and Bioscience Research Department, Teagasc, Grange) for extracting RNA from the liver tissue, L. J. Spicer for assistance with establishment of the IGF-1 iodination and RIA procedures, and A. F. Parlow of the National Hormone and Peptide Program (NHPP; Torrance, CA) for supplying the anti-human IGF-1 (hIGF-1) used in the IGF-1 RIA [NHPP-National Institute of Diabetes and Digestive and Kidney Diseases (NIDDK)]. Funding from the Teagasc Walsh Fellowship Scheme, the National Development Plan (Dublin, Ireland), and the Dairy Levy Trust is gratefully acknowledged.

\section{REFERENCES}

Bollwein, H., J. Lüttgenau, and K. Herzog. 2012. Bovine luteal blood flow: Basic mechanism and clinical relevance. Reprod. Fertil. Dev. 25:71-79.

Chomczynski, P., and N. Sacchi. 1987. Single-step method of RNA isolation by acid guanidinium thiocyanate-phenol-chloroform extraction. Anal. Biochem. 162:156-159.

Colazo, M. G., A. Dourey, R. Rajamahendran, and D. J. Ambrose. 2013. Progesterone supplementation before timed AI increased ovulation synchrony and pregnancy per AI, and supplementation after timed AI reduced pregnancy losses in lactating dairy cows. Theriogenology 79:833-841.

Cummins, S. B., P. Lonergan, A. C. O. Evans, D. P. Berry, R. D Evans, and S. T. Butler. 2012a. Genetic merit for fertility traits in Holstein cows: I. Production characteristics and reproductive efficiency in a pasture-based system. J. Dairy Sci. 95:1310-1322.

Cummins, S. B., P. Lonergan, A. C. O. Evans, and S. T. Butler. 2012b. Genetic merit for fertility traits in Holstein cows: II. Ovarian follicular and corpus luteum dynamics, reproductive hormones, and estrus behavior. J. Dairy Sci. 95:3698-3710.

Cummins, S. B., S. M. Waters, A. C. O. Evans, P. Lonergan, and S. T. Butler. 2012c. Genetic merit for fertility traits in Holstein cows: III. Hepatic expression of somatotropic axis genes during pregnancy and lactation. J. Dairy Sci. 95:3711-3721.

Cunha, A. P., J. G. Guenther, M. J. Maroney, J. O. Giordano, A. B. Nascimento, S. Bas, H. Ayres, and M. C. Wiltbank. 2008. Effects of high vs. low progesterone concentrations during Ovsynch on double ovulation rate and pregnancies per AI in high producing dairy cows. J. Dairy Sci. 91(Suppl. 1):246. (Abstr.)
Diskin, M. G., and D. G. Morris. 2008. Embryonic and early foetal losses in cattle and other ruminants. Reprod. Domest. Anim. 43(Suppl. 2):260-267.

Edmonson, A. J., I. J. Lean, L. D. Weaver, T. Farver, and G. Webster. 1989. A body condition scoring chart for Holstein dairy cows. J. Dairy Sci. 72:68-78.

Enright, W. J., L. T. Chapin, W. M. Moseley, S. A. Zinn, M. B. Kamdar, L. F. Krabill, and H. A. Tucker. 1989. Effects of infusions of various doses of bovine growth hormone-releasing factor on blood hormones and metabolites in lactating Holstein cows. J. Endocrinol. 122:671-679.

Forde, N., J. P. Mehta, P. A. McGettigan, S. Mamo, F. W. Bazer, T. E. Spencer, and P. Lonergan. 2013. Alterations in expression of endometrial genes coding for proteins secreted into the uterine lumen during conceptus elongation in cattle. BMC Genomics 14:321.

Herlihy, M. M., D. P. Berry, M. A. Crowe, M. G. Diskin, and S. T Butler. 2011. Evaluation of protocols to synchronize estrus and ovulation in seasonal calving pasture-based dairy production systems. J. Dairy Sci. 94:4488-4501.

Herlihy, M. M., M. A. Crowe, D. P. Berry, M. G. Diskin, and S. T. Butler. 2013. Factors associated with fertility outcomes in cows treated with protocols to synchronize estrus and ovulation in seasonal-calving, pasture-based dairy production systems. J. Dairy Sci. 96:1485-1498

Herlihy, M. M., M. A. Crowe, M. G. Diskin, and S. T. Butler. 2012. Effects of synchronization treatments on ovarian follicular dynamics, corpus luteum growth, and circulating steroid hormone concentrations in lactating dairy cows. J. Dairy Sci. 95:743-754.

Herzog, K., M. Brockhan-Lüdemann, M. Kaske, N. Beindorff, V. Paul, H. Niemann, and H. Bollwein. 2010. Luteal blood flow is a more appropriate indicator for luteal function during the bovine estrous cycle than luteal size. Theriogenology 73:691-697.

Hutchinson, I. A., R. J. Dewhurst, A. C. O. Evans, P. Lonergan, and S. T. Butler. 2012. Effect of grass dry matter intake and fat supplementation on progesterone metabolism in lactating dairy cows. Theriogenology 78:878-886.

Larson, S. F., W. R. Butler, and W. B. Currie. 2007. Pregnancy rates in lactating dairy cattle following supplementation of progesterone after artificial insemination. Anim. Reprod. Sci. 102:172-179.

Lemley, C. O., S. T. Butler, W. R. Butler, and M. E. Wilson. 2008 Short communication: Insulin alters hepatic progesterone catabolic enzymes cytochrome P450 2C and 3A in dairy cows. J. Dairy Sci. 91:641-645.

Lemley, C. O., K. A. Vonnahme, L. R. Tager, K. M. Krause, and M. E. Wilson. 2010a. Diet-induced alterations in hepatic progesterone (P4) catabolic enzyme activity and $\mathrm{P} 4$ clearance rate in lactating dairy cows. J. Endocrinol. 205:233-241.

Lemley, C. O., T. A. Wilmoth, L. R. Tager, K. M. Krause, and M. E. Wilson. 2010b. Effect of a high cornstarch diet on hepatic cytochrome $\mathrm{P} 4502 \mathrm{C}$ and $3 \mathrm{~A}$ activity and progesterone half-life in dairy cows. J. Dairy Sci. 93:1012-1021.

Lonergan, P. 2011. Influence of progesterone on oocyte quality and embryo development in cows. Theriogenology 76:1594-1601.

Lopes, A. S., S. T. Butler, R. O. Gilbert, and W. R. Butler. 2007. Relationship of pre-ovulatory follicle size, estradiol concentrations and season to pregnancy outcome in dairy cows. Anim. Reprod. Sci. 99:34-43.

Lüttgenau, J., S. E. Ulbrich, N. Beindorff, A. Honnens, K. Herzog, and H. Bollwein. 2011. Plasma progesterone concentrations in the mid-luteal phase are dependent on luteal size, but independent of luteal blood flow and gene expression in lactating dairy cows. Anim. Reprod. Sci. 125:20-29.

Macmillan, K. L., and A. J. Peterson. 1993. A new intravaginal progesterone releasing device for cattle (CIDR-B) for oestrous synchronisation, increasing pregnancy rates and the treatment of postpartum anoestrus. Anim. Reprod. Sci. 33:1-25.

Mann, G. E. 2009. Corpus luteum size and plasma progesterone concentration in cows. Anim. Reprod. Sci. 115:296-299.

McNeill, R. E., M. G. Diskin, J. M. Sreenan, and D. G. Morris. 2006. Associations between milk progesterone concentration on different 
days and with embryo survival during the early luteal phase in dairy cows. Theriogenology 65:1435-1441.

Murray, M. 1991. Microsomal cytochrome P450-dependent steroid metabolism in male sheep liver. Quantitative importance of $6 \beta$-hydroxylation and evidence for the involvement of a $\mathrm{P} 450$ from the IIIA subfamily in the pathway. J. Steroid Biochem. Mol. Biol. 38:611-619.

Murray, M. 1992. Participation of a cytochrome P450 enzyme from the 2C subfamily in progesterone 21-hydroxylation in sheep liver. J. Steroid Biochem. Mol. Biol. 43:591-593.

Nascimento, A. B., R. W. Bender, A. H. Souza, H. Ayres, R. R. Araujo, J. N. Guenther, R. Sartori, and M. C. Wiltbank. 2013a. Effect of treatment with human chorionic gonadotropin on day 5 after timed artificial insemination on fertility of lactating dairy cows. J. Dairy Sci. 96:2873-2882.

Nascimento, A. B., A. H. Souza, J. N. Guenther, F. P. Costa, R. Sartori, and M. C. Wiltbank. 2013b. Effects of treatment with human chorionic gonadotrophin or intravaginal progesterone-releasing device after $\mathrm{AI}$ on circulating progesterone concentrations in lactating dairy cows. Reprod. Fertil. Dev. 25:818-824.

Penning, T. M., M. E. Burczynski, J. M. Jez, C.-F. Hung, H.-K. Lin, H. Ma, M. Moore, N. Palackal, and K. Ratnam. 2000. Human $3 \alpha$-hydroxysteroid dehydrogenase isoforms (AKR1C1-AKR1C4) of the aldo-keto reductase superfamily: Functional plasticity and tissue distribution reveals roles in the inactivation and formation of male and female sex hormones. Biochem. J. 351:67-77.

R Core Team. 2013. R: A language and environment for statistical computing. R Foundation for Statistical Computing, Vienna, Austria. Accessed Apr. 28, 2014. http://www.R-project.org/.

Reynolds, C. K., P. C. Aikman, B. Lupoli, D. J. Humphries, and D. E. Beever. 2003. Splanchnic metabolism of dairy cows during the transition from late gestation through early lactation. J. Dairy Sci. $86: 1201-1217$.

Rizos, D., F. Carter, U. Besenfelder, V. Havlicek, and P. Lonergan. 2010. Contribution of the female reproductive tract to low fertility in postpartum lactating dairy cows. J. Dairy Sci. 93:1022-1029.

Rizos, D., S. Scully, A. K. Kelly, A. D. Ealy, R. Moros, P. Duffy, A. Al Naib, N. Forde, and P. Lonergan. 2012. Effects of human chorionic gonadotrophin administration on day 5 after oestrus on corpus luteum characteristics, circulating progesterone and conceptus elongation in cattle. Reprod. Fertil. Dev. 24:472-481.

Sangsritavong, S., D. K. Combs, R. Sartori, L. E. Armentano, and M. C. Wiltbank. 2002. High feed intake increases liver blood flow and metabolism of progesterone and estradiol-17 $\beta$ in dairy cattle. J. Dairy Sci. 85:2831-2842.

Sartori, R., J. M. Haughian, R. D. Shaver, G. J. M. Rosa, and M. C. Wiltbank. 2004. Comparison of ovarian function and circulating steroids in estrous cycles of Holstein heifers and lactating cows. J. Dairy Sci. 87:905-920.

SAS Institute. 2006. SAS User's Guide: Statistics. SAS Institute Inc., Cary, NC.

Senger, P. L. 1997. Pathways to Pregnancy and Parturition. Current Conceptions Inc., Pullman, Washington.

Siddiqui, M. A. R., M. Almamun, and O. J. Ginther. 2009. Blood flow in the wall of the preovulatory follicle and its relationship to pregnancy establishment in heifers. Anim. Reprod. Sci. 113:287-292.

Stevenson, J. L., J. C. Dalton, J. E. P. Santos, R. Sartori, A. Ahmadzadeh, and R. C. Chebel. 2008. Effect of synchronization protocols on follicular development and estradiol and progesterone concentrations of dairy heifers. J. Dairy Sci. 91:3045-3056.

Stronge, A. J. H., J. M. Sreenan, M. G. Diskin, J. F. Mee, D. A. Kenny, and D. G. Morris. 2005. Post-insemination milk progesterone concentration and embryo survival in dairy cows. Theriogenology 64:1212-1224

Walker, C. G., M. D. Littlejohn, M. D. Mitchell, J. R. Roche, and S. Meier. 2012. Endometrial gene expression during early pregnancy differs between fertile and subfertile dairy cow strains. Physiol. Genomics 44:47-58.

Wiltbank, M. C. 1994. Cell types and hormonal mechanisms associated with mid-cycle corpus luteum function. J. Anim. Sci. 72:1873-1883.

Wiltbank, M. C., R. Sartori, M. M. Herlihy, J. L. M. Vasconcelos, A. B. Nascimento, A. H. Souza, H. Ayres, A. P. Cunha, A. Keskin, J. N. Guenther, and A. Gumen. 2011. Managing the dominant follicle in lactating dairy cows. Theriogenology 76:1568-1582.

Wolfenson, D., G. Inbar, Z. Roth, M. Kaim, A. Bloch, and R. BrawTal. 2004. Follicular dynamics and concentrations of steroids and gonadotropins in lactating cows and nulliparous heifers. Theriogenology 62:1042-1055.

Xu, Z. Z., L. J. Burton, and K. L. Macmillan. 1997. Reproductive performance of lactating dairy cows following estrus synchronization regimens with $\mathrm{PGF}_{2 \alpha}$ and progesterone. Theriogenology $47: 687-701$ 